\title{
PENINGKATAN PRODUKTIVITAS TERNAK SAPI POTONG MELALUI PENERAPAN TEKNOLOGI PETERNAKAN DI KELOMPOK TANI KOTA DALE - KELURAHAN OESAO
}

\author{
Melkianus Dedimus Same Randu, Ferdinan S. Suek, dan Thomas Lapenangga \\ Program Studi Produksi Ternak, Politeknik Pertanian Negeri kupang \\ E-mail: deddy_randu@yahoo.co.id
}

\begin{abstract}
ABSTRAK
Kegiatan Ipteks bagi Masyarakat (IbM) bertujuan untuk meningkatkan pengetahuan dan keterampilan anggota mitra kelompok tani Kota Dale tentang pemanfaatan berbagai teknologi bidang peternakan dalam usaha ternak sapi potong yang murah, dan mudah diaplikasikan di tingkat peternak. Kegiatan IbM dilakukan pada kelompok tani Kota Dale I dan Kota Dale II berdasarkan pertimbangan aktivitas mitra kelompok tani yang selama ini melakukan usaha pemeliharaan ternak sapi potong secara tradisional, bersifat sambilan, dan kurang memanfaatkan teknologi peternakan yang aplikatif sehingga turut mempengaruhi terhadap peningkatan produktivitas ternak sapi potong maupun perkembangan ekonomi rumah tangga. Kegiatan IbM diterapkan menggunakan metode ceramah, diskusi, demplot, pendampingan, dan monev. Implementasi kegiatan dilakukan dengan introduksi teknologi perkandangan dan teknologi pengolahan pakan, serta diseminasi informasi usaha pemeliharaan sapi potong. Hasil yang dicapai dari kegiatan IbM adalah peningkatan pengetahuan, kesadaran, dan keterampilan anggota mitra kelompok tani dalam memanfaatkan berbagai teknologi peternakan yang diadopsi dalam usaha ternak sapi potong, meliputi: teknologi dan manajemen perkandangan, teknologi dan manajemen pangolahan. Luaran yang dihasilkan dari kegiatan IbM, antara lain: kandang sapi penggemukan (paronisasi) berukuran 1,8 x 2 m sebanyak 4 unit; silase jagung sebanyak 500 $\mathrm{kg}$, dan jerami padi fermentasi sebanyak $500 \mathrm{~kg}$. Kegiatan IbM telah memberikan manfaat bagi anggota mitra kelompok tani dalam upaya menerapkan sistem manajemen usaha sapi potong yang efisien dan ekonomis, dengan memanfaatkan inovasi teknologi dalam bidang peternakan.
\end{abstract}

Kata Kunci: Kesadaran, Keterampilan, Pengetahuan, Sapi Potong, Teknologi. 


\section{PENDAHULUAN}

Kota Dale I dan Kota Dale II merupakan mitra kelompok tani IbM yang terletak di RT 12, RW 06, Kelurahan Oesao, Kecamatan Kupang Timur, Kabupaten Kupang. Kelompok mitra tersebut talah terbentuk sejak tahun 2010 dan memiliki anggota sebanyak 25 orang, dengan dominasi latar belakang pendidikan adalah tamatan SMA/sederajat. Mitra kelompok tani dibentuk berdasarkan kesepakatan bersama untuk menjalankan aktivitas usaha pertanian, melalui budidaya padi sawah, jagung, serta penggemukan (paronisasi) ternak sapi potong. Usaha tersebut turut memberikan kontribusi dalam perkembangan ekonomi rumah tangga.

Profil aktivitas pertanian yang dilakukan mitra IbM umumnya bersifat tradisional. Anggota mitra belum memanfaatkan limbah pertanian dalam menunjang pemeliharaan sapi potong. Limbah yang dihasilkan dari tanaman pertanian (jerami padi dan batang jagung) selama ini hanya dibiarkan kering dan dibakar, serta tidak digunakan secara optimal sebagai pakan. Sapi potong umumnya dipelihara anggota mitra IbM secara ekstensif (dilepas dalam jangka waktu lama), dan sebagian lainnya menggunakan sistem ikat pindah dalam kegiatan paronisasi. Jenis pakan yang dominan diberikan oleh anggota mitra adalah rumput alam, yang kontinuitasnya sangat dipengaruhi oleh musim. Paronisasi dengan sistem ikat pindah membutuhkan waktu lama (10-12 bulan) untuk meningkatkan pertambahan bobot badan, dan rentan terhadap penyakit maupun cekaman cuaca.

Anggota mitra kelompok tani IbM dalam menjalankan usaha sapi potong belum memanfaatkan teknologi peternakan, terutama dalam mengelola potensi limbah pertanian (padi sawah dan jagung). Hambatan lain yang ditemui berkaitan dengan kurangnya informasi yang berkaitan dengan tatalaksana maupun implementasi teknologi usaha sapi potong. Kondisi tersebut pada akhirnya mempengaruhi peningkatan produktivitas sapi potong, menghambat adopsi inovasi teknologi peternakan, dan mempengaruhi kondisi ekonomi rumah tangga mitra.

Pemerintah Kabupaten Kupang telah berupaya mengatasi kendala yang dialami mitra melalui pelatihan adopsi dan inovasi teknologi bidang peternakan, namun belum mampu memperbaiki pola aktivitas usahatani yang dijalankan, akibat terbatasnya jumlah anggota mitra yang dilibatkan dalam pelatihan, rentang waktu pelatihan yang singkat, dan tidak 
diterapkannya mekanisme pendampingan berkelanjutan. Menyikapi hal tersebut, kegiatan IbM bertujuan untuk meningkatkan partisipasi, kesadaran, pengetahuan, dan keterampilan seluruh anggota mitra dalam menerapkan tatalaksana usaha sapi potong yang efektif dan efisien melalui pemanfaatan teknologi. Hal tersebut secara implementatif dilakukan melalui introduksi teknologi perkandangan maupun pengolahan pakan.

\section{MASALAH}

Berdasarkan uraian sebelumnya, dapat diidentifikasi dan dirumuskan beberapa masalah yang berkaitan dengan tatalaksana usaha sapi potong di kelompok tani Kota Dale I dan II, antara lain:

1. Terbatasnya pengetahuan anggota mitra kelompok tani IbM tentang sistem tatalaksana usaha sapi potong yang efektif dan efisien.

2. Kurangnya pemahaman dan kesadaran anggota mitra kelompok tani IbM dalam memanfaatkan potensi limbah pertanian secara optimal untuk menunjang aktivitas usaha pemeliharaan ternak sapi potong.

3. Terbatasnya pengetahuan dan keterampilan anggota mitra kelompok tani IbM tentang pemanfaatan teknologi perkandangan maupun pengolahan pakan.

\section{METODE PELAKSANAAN}

Kegiatan IbM dilakukan pada kelompok tani Kota Dale I dan II yang berlokasi di Kelurahan Oesao, Kecamatan Kupang Timur, Kabupaten Kupang, Provinsi Nusa Tenggara Timur. Kegiatan IbM dijalankan selama \pm 8 (delapan) bulan dengan melibatkan seluruh anggota kelompok tani Kota Dale I dan Kota Dale II.

Kegiatan IbM dilaksanakan dalam dua tahapan, yaitu persiapan dan pelaksanaan. Tahapan persiapan meliputi observasi permasalahan mitra, sosialisasi rencana kegiatan, penyiapan alat dan bahan, serta persiapan narasumber. Tahapan pelaksanaan meliputi penyampaian informasi (materi) yang berkaitan dengan luaran IbM baik secara lisan (oral) maupun tulisan (leaflet), pelaksanaan diskusi tentang permasalahan anggota mitra kelompok tani IbM maupun isi 
materi penyuluhan yang belum dipahami, penerapan demonstrasi plot teknologi peternakan, pendampingan anggota mitra kelompok tani dalam introduksi teknologi peternakan, monitoring dan bimbingan teknis penerapan teknologi peternakan dan sistem tatalaksana usaha sapi potong, serta evaluasi pelaksanaan kegiatan IbM.

Kegiatan IbM secara teknis dilakukan menggunakan metode ceramah, diskusi, demonstrasi plot (demplot), pendampingan, serta monitoring dan evaluasi. Materi yang disampaikan dalam kegiatan IbM, meliputi: sistem dan teknis perkandangan ternak sapi potong, pembuatan silase jagung, dan pembuatan jerami padi fermentasi.

\section{HASIL YANG DICAPAI}

Kegiatan IbM di Kelompok Tani Kota Dale I dan Kota Dale II memiliki indikator hasil yang diketahui dari pertambahan bobot badan harian (PBBH) sapi potong yang diberikan silase jagung + jerami padi fermentasi, dan peningkatan partisipasi anggota mitra untuk mengikuti kegiatan penyuluhan dan demplot. Pengamatan yang dilakukan akhir kegiatan diketahui bahwa anggota mitra kelompok tani telah memiliki kesadaran untuk mengandangkan ternak sapi yang dipelihara pada kegiatan paronisasi, memanfaatkan jerami padi dan batang, daun jagung (limbah pertanian) sebagai pakan ternak sapi potong. Anggota mitra kelompok tani IbM juga telah mempunyai keterampilan khususnya dalam membuat silase jagung maupun jerami padi fermentasi (pengolahan pakan). Hal lain yang turut menjadi perhatian dari kegiatan IbM adalah kesadaran dari anggota mitra kelompok tani untuk menjaga kontinuitas pakan pada musim kemarau melalui strategi pemanfaatan dan penerapan teknologi pengolahan pakan. Pelaksanaan dan dokumentasi kegiatan, sebagai berikut:

1. Penyuluhan dan demplot pembuatan kandang paronisasi telah meningkatkan pengetahuan anggota mitra kelompok tani tentang manfaat kandang; meningkatkan keterampilan pembuatan kandang yang sesuai syarat teknis; menghasilkan empat unit kandang yang dapat digunakan untuk kegiatan paronisasi; menimbulkan kesadaran mengandangkan ternak sebagai upaya mempercepat waktu paronisasi (Gambar 1). 

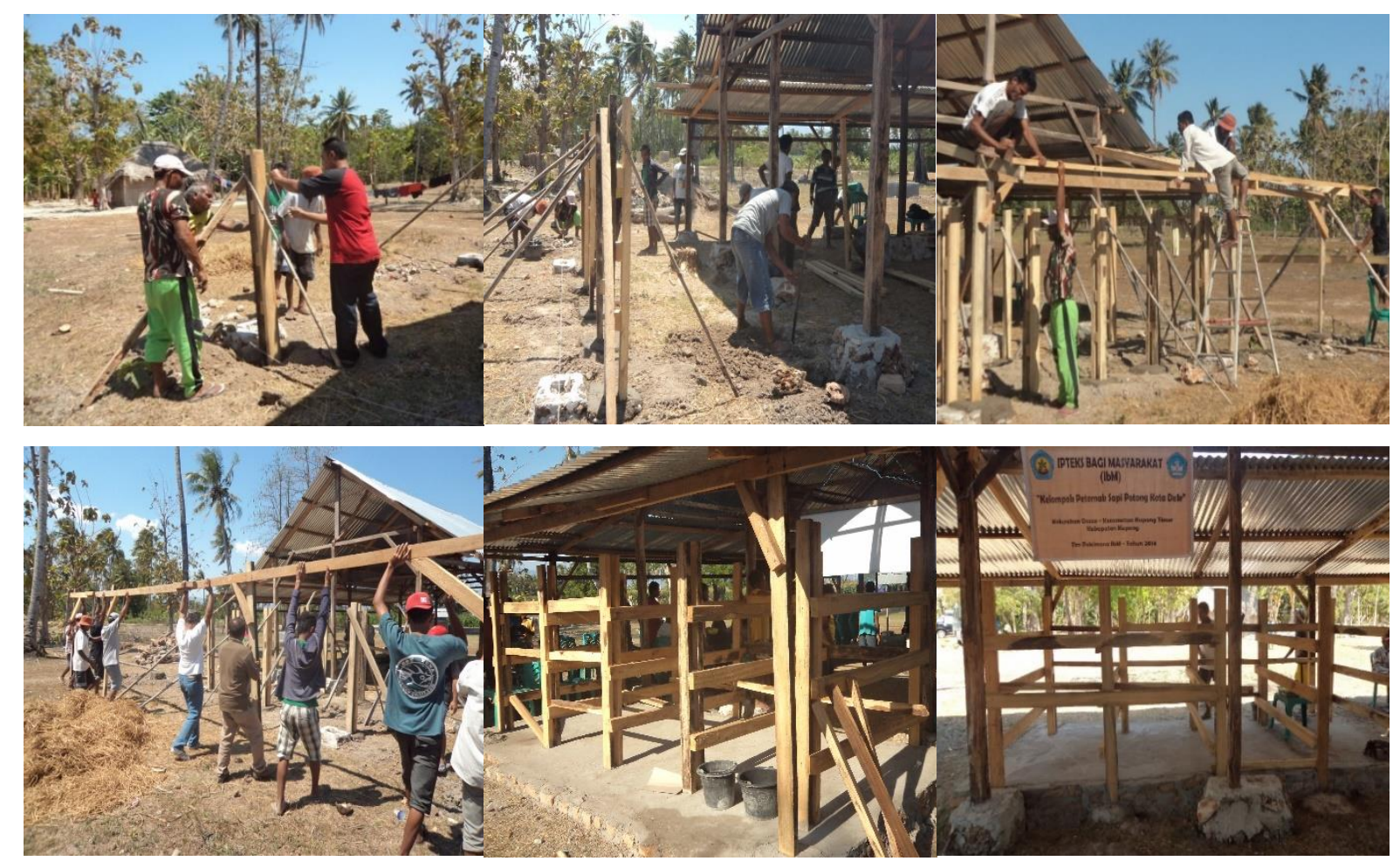

Gambar 1. Penerapan Teknologi Perkandangan Sapi Potong.

2. Penyuluhan dan demplot teknologi pembuatan silase jagung telah meningkatkan pengetahuan anggota mitra IbM tentang manfaat limbah jagung dalam mendukung usaha peternakan dan sumber pakan bagi ternak sapi potong yang digemukkan (paronisasi); meningkatkan pengetahuan anggota mitra IbM tentang ciri-ciri fisik silase yang baik, kesadaran untuk memanfaatkan limbah tanaman jagung yang selama ini dibiarkan terbuang atau belum diolah; keterampilan dalam membuat dan menerapkan teknologi pengolahan pakan (silase) menggunakan limbah pertanian (batang dan daun jagung); pemahaman tentang pentingnya strategi penyediaan pakan berkelanjutan di musim kemarau; dan produksi silase sebanyak $500 \mathrm{Kg}$ (Gambar 2). 

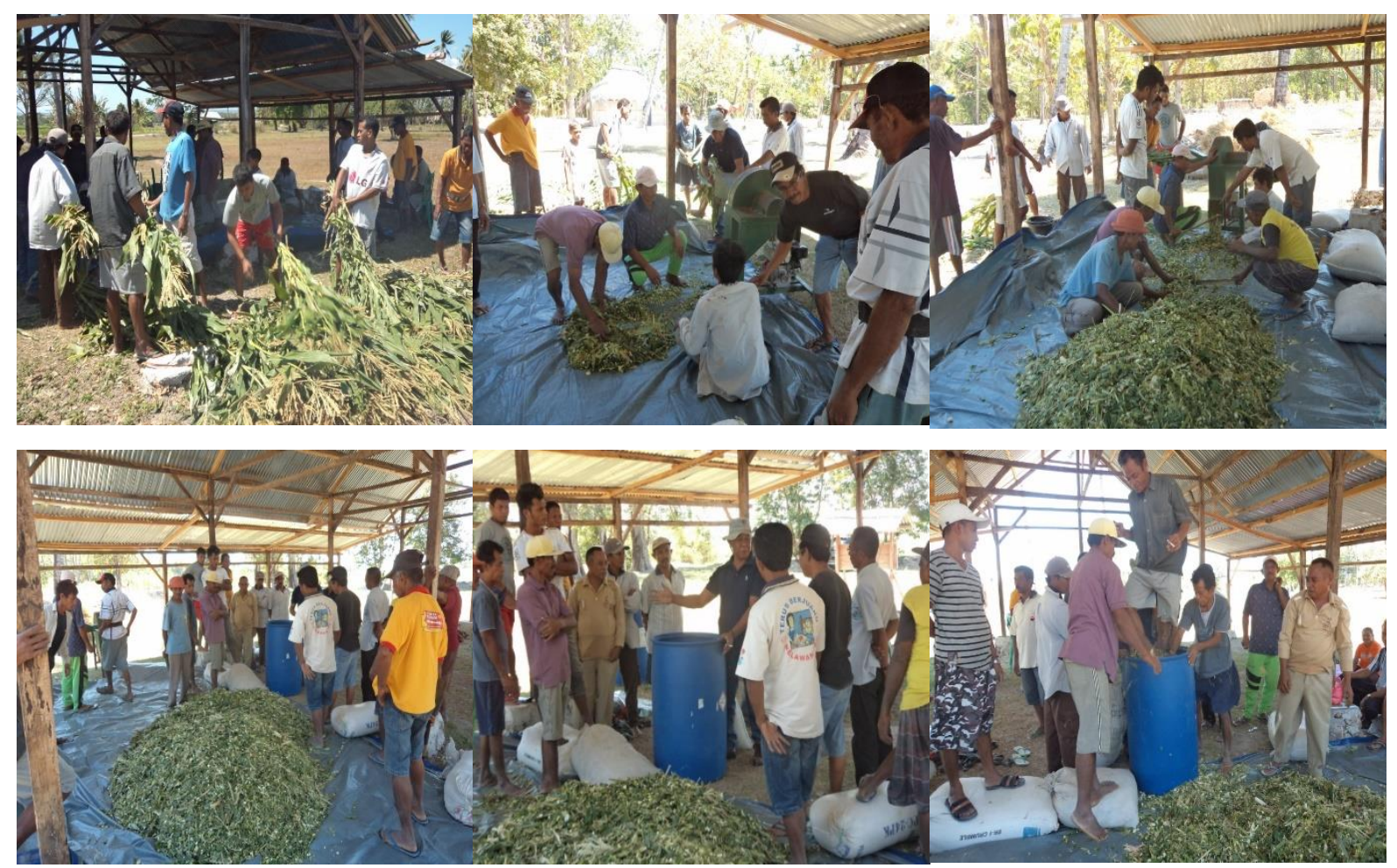

Gambar 2. Penerapan Teknologi Silase Jagung.

3. Penyuluhan dan demplot teknologi pembuatan jerami padi fermentasi telah meningkatkan pengetahuan anggota mitra IbM tentang manfaat limbah tanaman padi sebagai sumber pakan alternatif bagi ternak sapi potong yang dipelihara terutama pada musim kemarau; meningkatkan pengetahuan anggota mitra IbM tentang ciri-ciri fisik jerami padi fermentasi yang baik; kesadaran untuk memanfaatkan jerami padi yang selama ini tidak digunakan dan selalu dibakar; keterampilan dalam membuat dan menerapkan teknologi jerami padi fermentasi menggunakan limbah tanaman padi; dan produksi jerami padi fermentasi sebanyak $500 \mathrm{Kg}$ (Gambar 3). 

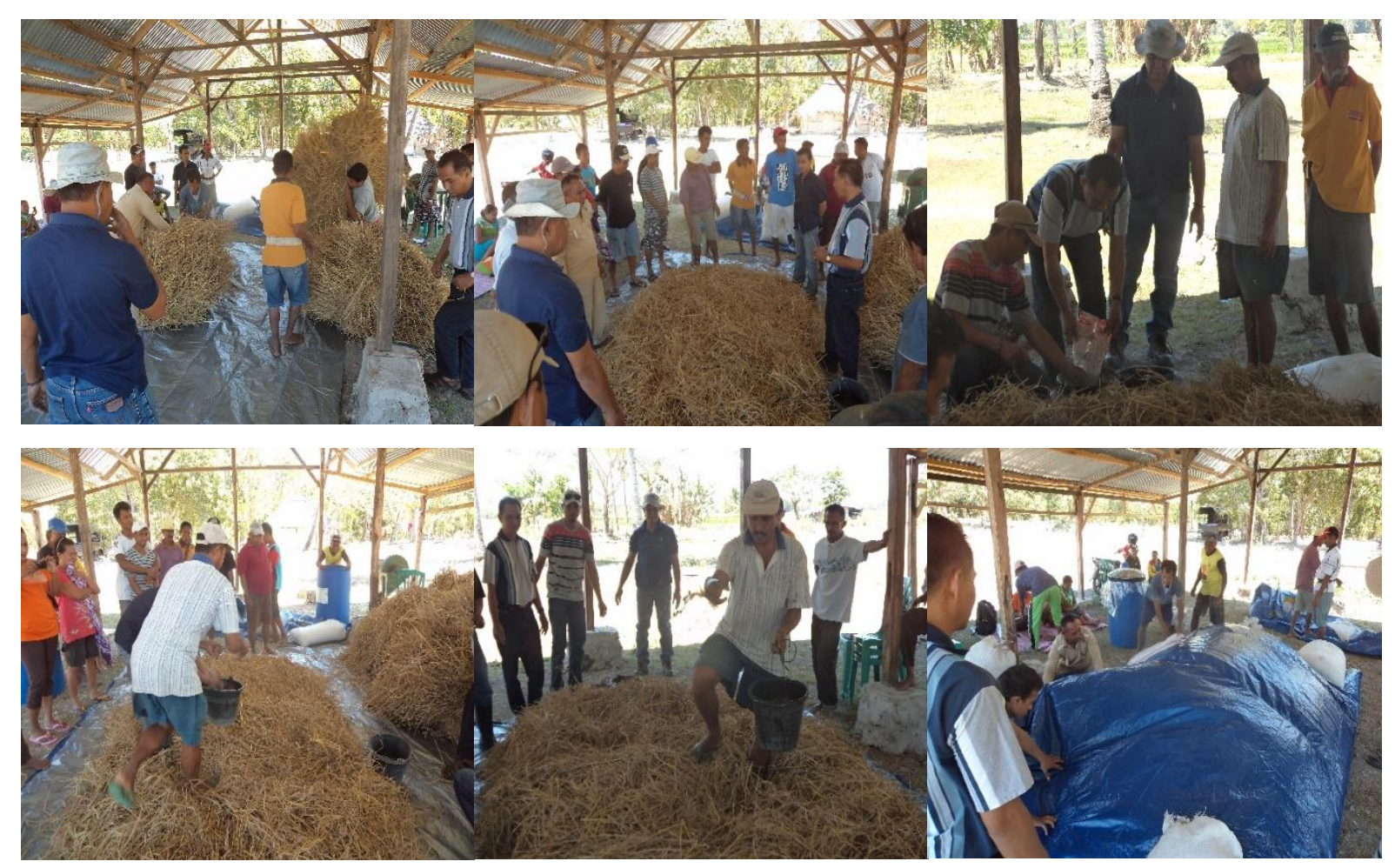

Gambar 3. Penerapan Teknologi Jerami Padi Fermentasi.

4. Monitoring dan evaluasi (monev) pelaksanaan kegiatan IbM telah dilakukan oleh tim pelaksana IbM dan tim DRPM Dikti. Hasil monev menunjukkan bahwa introduksi teknologi peternakan (perkandangan dan pengolahan pakan) di tingkat peternak telah berhasil diimplementasikan. Indikator yang dihasilkan dari kegiatan monev, meliputi : kemampuan mitra yang secara swadaya dan mandiri mampu membuat kandang sapi percontohan, silase jagung, dan jerami padi fermentasi; tersedianya produk silase jagung dan jerami fermentasi yang diujicobakan pada ternak sapi; kesepakatan untuk tidak membakar/ memberikan limbah hasil pertanian kepada orang lain di luar anggota kelompok Kota Dale; melakukan kegiatan bergilir pengolahan pakan; dan menyepakati penggunaan kandang contoh sebagai model melakukan kegiatan paronisasi (Gambar 4). 

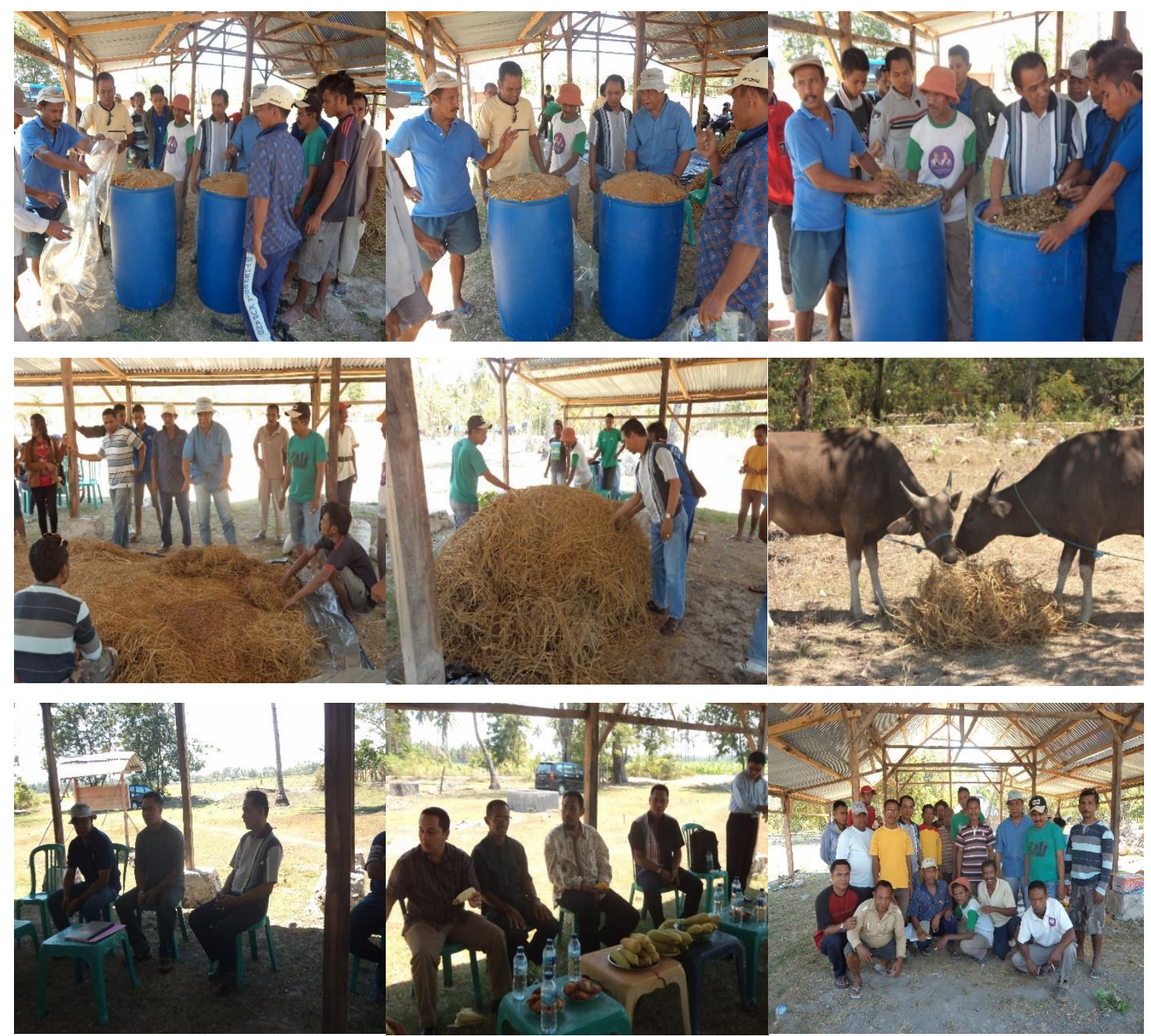

Gambar 4. Monitoring dan Evaluasi Pelaksanaan IbM.

Meskipun demikian, secara teknis diketahui terdapat beberapa kendala yang dialami selama rangkaian pelaksanaan kegiatan IbM yang sekiranya dapat menjadi evaluasi dan perbaikan tersendiri untuk kegiatan IbM pada masa mendatang. Berbagai kendala dimaksud, antara lain:

1. Terdapat beberapa perubahan jadwal yang telah disepakati bersama sebelumnya dengan pengurus dan anggota kelompok tani Kota Dale I dan Kota Dale II akibat kegiatan isidentil (mendadak) yang tidak dapat dihindari oleh sebagian besar anggota kelompok tani terutama dalam urusan kedukaan maupun perkawinan mengakibatkan terjadinya penundaan dan penggabungan pada beberapa kegiatan IbM yang direncanakan. 
2. Waktu pelaksanaan kegiatan IbM yang bergeser dari kesepakatan yang telah ditentukan oleh tim pelaksana dan anggota kelompok tani akibat jarak yang cukup jauh dari lokasi pelaksanaan kegiatan dengan tempat tinggal tim pelaksana IbM dan narasumber, sehingga pada beberapa kegiatan penyuluhan maupun demplot mengalami keterlambatan dari sisi waktu pelaksanaan.

\section{SIMPULAN DAN SARAN}

Pelaksanaan kegiatan Ipteks bagi Masyarakat (IbM) yang dilaksanakan di Kelompok Tani Kota Dale I dan Kota Dale II memberikan manfaat positif terutama dalam kerangka pengelolaan sistem manajemen usaha ternak sapi potong melalui adopsi teknologi bidang peternakan. Kegiatan IbM yang dilaksanakan telah menghasilkan beberapa luaran sebagai produk yang dapat diimplementasikan untuk mendukung kegiatan paronisasi ternak sapi.

Berdasarkan hasil kegiatan IbM disarankan untuk melakukan pengembangan introduksi teknologi peternakan secara berkelanjutan melalui penerapan sistem usaha tani terpadu yang memanfaatkan limbah-limbah hasil pertanian lainnya. Pada masa mendatang sekiranya perlu dipertimbangkan untuk menerapkan teknologi biogas sebagai sumber energi alternatif yang dapat memberikan banyak manfaat bagi kelompok tani.

\section{DAFTAR PUSTAKA}

Anonimous, 2008. Hijauan Makanan Ternak. http://www.disnak.jabarprov.go.id/images/ artikel/hijauan.doc. Diakses 05 September 2012.

Anonimous, 2008. Produksi Biogas dari Limbah Ternak. Inforomasi Paket teknologi. Pusat penelitian Kopi dan Kako Indonesia. http://pustaka.litbang. deptan.go.id/agritek /kopi08.pdf. Diakses 12 April 2013.

Anonimous, 2012. Kabupaten Kupang dalam Angka Tahun 2011. Badan Pusat Statistik Kabupaten Kupang. Kupang. 
Antari R., dan U. Umiyasih, 2009. Profil Tata Laksana Pemeliharaan dan Pakan Sapi Potong Pembibitan di Daerah Sentra Industri Tepung Tapioka Skala Rakyat: Studi Kasus di Kecamatan Pundong, Kabupaten Bantul, Daerah Istimewa Yogyakarta. Seminar Nasional Teknologi Peternakan dan Veteriner. Halaman: 233-239.

Sadono, 2008. Pemberdayaan Petani: Paradigma Baru Penyuluhan Pertanian di Indonesia. Jurnal Penyuluhan. 4 (1): 65-74

Tonbesi, T. T., N. Ngadiyono, dan Sumadi, 2009. Estimasi Potensi dan Kinerja Sapi Bali di Kabupaten Timor Tengah Utara, Propinsi Nusa Tenggara Timur. Buletin Peternakan. 33 (1): 30-39.

Yunasaf U., dan D. S. Taspirin, 2011. Peran Penyuluh dalam Proses Pembelajaran Peternak Sapi Perah di KSU Tandangsari Sumedang. Jurnal Ilmu Ternak. 11 (2): 98-103. 